\title{
OPTIMASI PENYUSUNAN BARANG DALAM RANGKA MENINGKATKAN UTILITAS AKTIVITAS LOADING MENGGUNAKAN SOFTWARE CUBE IQ DI PT.ASR
}

\section{OPTIMIZATION FOR PREPARATION OF GOODS IN ORDER TO IMPROVE LOADING ACTIVITIES USING IQ CUBE SOFTWARE IN PT. ASR}

\author{
Sri Wardani ${ }^{1}$, Namun Mulyadi2), Nitta Fitria Anggraeni ${ }^{3)}$ \\ ${ }^{1,2,3)}$ Program Studi Teknik Industri, Fakultas Teknik, Universitas Widyatama, Bandung, Indonesia
}

\section{ARTICLE INFORMATION}

\section{Article history:}

Received: February 00, 00

Revised: March 00, 00

Accepted: April 00, 00

Keywords:

Loading Activity

Arrangement of goods

Software

Cube IQ

Keywords:

Aktivitas Loading

Penyusunan Barang

Perangkat Lunak

Cube IQ

\begin{abstract}
A B S T R A C T
Loading into containers must consider the level of efficient use of container space. The use of empty space and the arrangement of goods in containers that have not been optimal are problems in the process of loading goods. In this regard, the plan for the preparation of goods to be made by researchers is assisted with a software that will facilitate the optimal arrangement of goods arranged in containers. The parameters are reviewed from the aspect of purpose, weight, volume, and type of goods to see whether the optimal use of goods. Cube IQ became the software chosen to help implement the system in this study by determining the coordinates and $3 \mathrm{D}$ visualization of the arrangement of goods in containers. Goods data and container data become the data used in the simulation process. Dimensions (length, width, height) define the required item data. While dimensions (maximum weight and volume of containers) defines the required container data. After simulating the Cube IQ software there was an increase in the use of container capacity by $88.35 \%$ while manually only $87.91 \%$. The implication is a decrease in distribution costs per unit, which is $0.5 \%$. The optimization results obtained are expected to be able to provide input in making decisions determining the optimal arrangement of goods and fleet numbers.
\end{abstract}

\section{A B S T R A K}

Pemuatan ke dalam kontainer harus mempertimbangkan tingkat efisiensi penggunaan ruang kontainer. Penggunaan ruang kosong dan penyusunan barang dalam kontainer yang belum optimal menjadi permasalahan proses muat barang. Berkaitan dengan hal itu, rencana penyusunan barang yang akan dibuat oleh peneliti dibantu dengan suatu perangkat lunak yang akan memudahkan simulasi penataan barang yang optimal pada kontainer. Parameter ditinjau dari aspek tujuan, berat, volume, dan jenis barang untuk melihat optimal tidaknya penyusunan barang. Cube IQ menjadi software yang dipilih untuk membantu mengimplementasikan sistem dalam penelitian ini dengan penentuan titik koordinat dan visualisasi 3D penataan barang pada kontainer. Data barang dan data kontainer menjadi data yang digunakan pada proses simulasi. Dimensi (panjang, lebar, tinggi) mendefinisikan data barang yang diperlukan. Sementara dimensi (berat dan volume maksimum kontainer) mendefiniskan data kontainer yang diperlukan. Setelah dilakukan simulasi dengan software Cube $I Q$ terdapat peningkatan penggunaan kapasitas kontainer sebesar $88,35 \%$ sedangkan secara manual hanya $87,91 \%$. Implikasinya terjadi penurunan biaya distribusi per unit yaitu sebesar $0,5 \%$ Hasil optimasi yang diperoleh diharapkan mampu memberi masukan dalam pengambilan keputusan menentukan penyusunan barang dan jumlah armada yang optimal.

This is an open access article under the CC-BY license.

${ }^{*}$ Corresponding Author :

Sri Wardani

Email : dedewardani@ymail.com

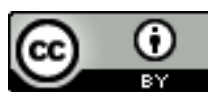




\section{PENDAHULUAN}

Pelaku dunia industri saat ini selalu dituntut untuk bekerja lebih cepat guna memenuhi permintaan pasar dan menghindari kehilangan peluang dalam berbisnis.[1] Untuk mendukung hal tersebut dibutuhkan suatu sistem yang efektif dan efisien. Suatu kegiatan industri dapat dilihat tingkat efektif dan efisiennya dari berbagai aspek salah satunya yaitu dalam manajemen gudang. Gudang memiliki pekerjaan utama seperti penyimpanan, penerimaan, dan pengiriman barang maka untuk menghasilkan sistem yang efektif dan efisien dibutuhkan rancangan gudang yang dapat menekan biaya dan memberikan pelayanan yang baik pada pelanggannya. [2]

Produktivitas gudang bergantung pada kelancaran aktivitas gudang, salah satunya aktivitas loading. Salah satu yang menjadi faktor kelancaran aktivitas loading yaitu berpindahannya suatu barang dari tempat penyimpanan sementara, kemudian mengantarkan kepada konsumen. Penyimpanan dan penyusunan barang dalam kontainer yang tepat mendukung kelancaran aktivitas loading menjadi efektif dan efisien yang membuat produktivitas gudang meningkat.[3]

Selain produktivitas gudang kunci penting dari kegiatan logistik setelah standar pelayanan perusahaan ialah transportasi, transportasi memiliki andil yang besar dalam tingkat kepuasan pelanggan dan kepentingan bisnis perusahaan.[4]

Kontainer atau peti kemas adalah alat pengangkut barang yang bisa digunakan diberbagai moda transportasi untuk melakukan aktivitas pengiriman barang. Penataan barang dalam peti kemas (container loading) merupakan langkah awal yang penting untuk mendistribusikan barang dengan berbagai macam berat dan ukuran dengan cara memaksimalkan pemanfaatan ruang yang tersedia dalam kontainer. Container loading menjadi inti dari banyak permasalahan yang muncul di dalam aktivitas logistik dan distribusi.[5]

Container loading merupakan kendala yang berkaitan dengan dimensi volume kendaraan karena adanya batasan kapasitas, dalam pengaturan dan penyusunan barang di dalam kontainer. Sehingga untuk mengatasinya perlu dilakukan pengoptimalan penggunaan kontainer untuk aktivitas tersebut.[6] Penumpukan barang didalam kontainer akan menjadi maksimal jika antara barang dan kontainer memiliki perbandingan dimensi serta volume yang sesuai. Langkah awal penyusunan barang didalam kontainer yaitu mengurutkan penyimpanan barang yang akan dimuat. Faktor kapasitas dan penyimpanan barang dalam sebuah kontainer yang tidak optimal akan membutuhkan biaya yang berlipat ganda karena dibutuhkan armada lain untuk mengangkut sisa barang yang seharusnya bisa dimasukkan dalam satu kontainer, dan juga para helper yang mengalami bertambahnya tingkat kelelahan.

Armada yang tidak dikelola dengan baik tidak hanya mahal tetapi juga meningkatkan risiko dan berdampak buruk bagi lingkungan. Terbukti, manajemen armada yang buruk juga dapat menyebabkan hilangnya target pengiriman program karena tidak tersedianya kendaraan.[7]

Cube IQ merupakan salah satu software yang dapat membantu dalam hal perencanaan aktivitas loading dengan baik dan teratur, jika diterapkan pada aktivitas loading yang sebenarnya, maka akan mendekati hasil seperti apa yang telah diproses dalam sistem ini. Cube IQ mempunyai mode operasi untuk container loading, truck loading, palletization dan cartonization.

Saat ini solusi teknologi informasi semakin terlihat penting dalam kegiatan perusahaan untuk permasalah penyusunan barang didalam kontainer. Jika rencana penyusunan barang pada ruang tiga dimensi dapat dibuat dengan suatu perangkat lunak (software), maka akan memudahkan perusahaan untuk melakukan kegiatan pengiriman barang dan biaya yang dikeluarkan dapat ditekan.

PT ASR merupakan perusahaan yang bergerak dibidang agrokimia yang menyediakan layanan penuh mulai dari pengembangan, pengadaan, pemrosesan, pergudangan hingga distribusi produk kimia. Produk yang dihasilkan yaitu pestisida dengan sedian powder dan liquid yang dikemas menggunakan box dan drum agar dapat menghemat biaya logistik dan mempermudah dalam aktivitas logistik. Kondisi pemuatan barang di PT ASR saat ini untuk sistem distribusi belum berjalan dengan baik, hal ini dapat dilihat dari satu aktivitas loading karena jumlah barang yang akan didistribusikan kepada pelanggan tidak mampu dimuat kedalam kontainer secara optimal. Berdasarkan hasil pengamatan kegiatan loading di PT.ASR, khusus pada produk pestisida mendapat permintan rata-rata sebanyak 1733 karton, sedangkan data dari perusahaan didapat bahwa PT.ASR hanya dapat memenuhi 1485 karton untuk satu kali aktivitas loading, sehingga jika dihitung biaya untuk 1 karton yang dimuat mempunyai biaya yang lebih tinggi. Pengurutan, penyusunan, kombinasi, dan orientasi posisi barang yang kurang tepat yang menjadikan hal ini 
terjadi. Jika dalam proses penyusunan barang tidak tepat terjadi terus menerus, maka cost yang dikeluarkan untuk biaya distribusi akan membengkak, selain itu akan semakin sering terjadi kerusakan barang yang akan dikirimkan dan mengalami kesulitan dalam proses pengambilan barang. Sehingga kondisi ini akan sangat mengkhawatirkan jika tidak ditanggulangi dengan baik, karena PT. ASR merupakan manufaktur yang bekerja untuk memenuhi kebutuhan konsumen dan perusahaan bisa mengeluarkan biaya pengiriman yang besar bila pengisian barang kedalam kontainer tidak dapat dilakukan secara maksimal.

Berdasarkan latar belakang permasalahan yang telah dikemukan diatas, maka rumusan masalah dari penelitian ini yaitu bagaimana menentukan jumlah armada yang akan digunakan melalui penyusunan, pengurutan dan orientasi barang yang optimal dalam kontainer dengan aplikasi software Cube IQ pada PT. ASR, serta efek aplikasi software Cube IQ terhadap utilitas volume serta berat kontainer dalam aktivitas loading pada PT ASR dapat diketahui. Hasil dari perencanaan loading menggunakan aplikasi software Cube IQ dapat mendekati hasil yang ada dilapangan. Sehingga hasil dari penelitian ini diharapkan dapat menjadi masukan bagi pihak perusahaan dalam pengambilan keputusan menentukan jumlah armada yang optimal.

\section{METODE PENELITIAN}

Penelitian dilakukan di PT. ASR yang berada di kota Bogor, Jawa Barat. Penelitian ini dilaksanakan mulai 07 - 14 Maret 2020. Objek penelitian yang diamati adalah aktivitas loading pada unit bongkar muat PT. ASR yang dilakukan dengan truk kontainer. Aktivitas loading tersebut yaitu memindahkan produk jadi dari warehouse ke truk kontainer. Tahap pengumpulan data pada penilitian ini dilakukan dengan melakukan pengamatan dan pengkuran secara langsung pada aktivitas loading, yaitu memindahkan produk jadi dari warehouse ke truk kontainer. Adapun data yang diambil secara pengukuran langsung maupun dari dokumen perusahaan yaitu, jenisjenis produk jadi, berat produk, jumlah permintaan produk jadi, dan data spesifikasi master box.[8] Kemudian data diolah dengan menggunakan metode-metode pengolahan data agar inti permasalahan dapat diketahui dengan jelas dan dapat menjadi pertimbangan peneliti dalam mengambil keputusan Metode-metode pengolahan data yang dilakukan adalah perhitungan jumlah produk jadi yang dimuat sesuai permintaan dan perencanaan loading menggunakan aplikasi software Cube IQ. Alur penelitian ini ditunjukkan pada Gambar 1.

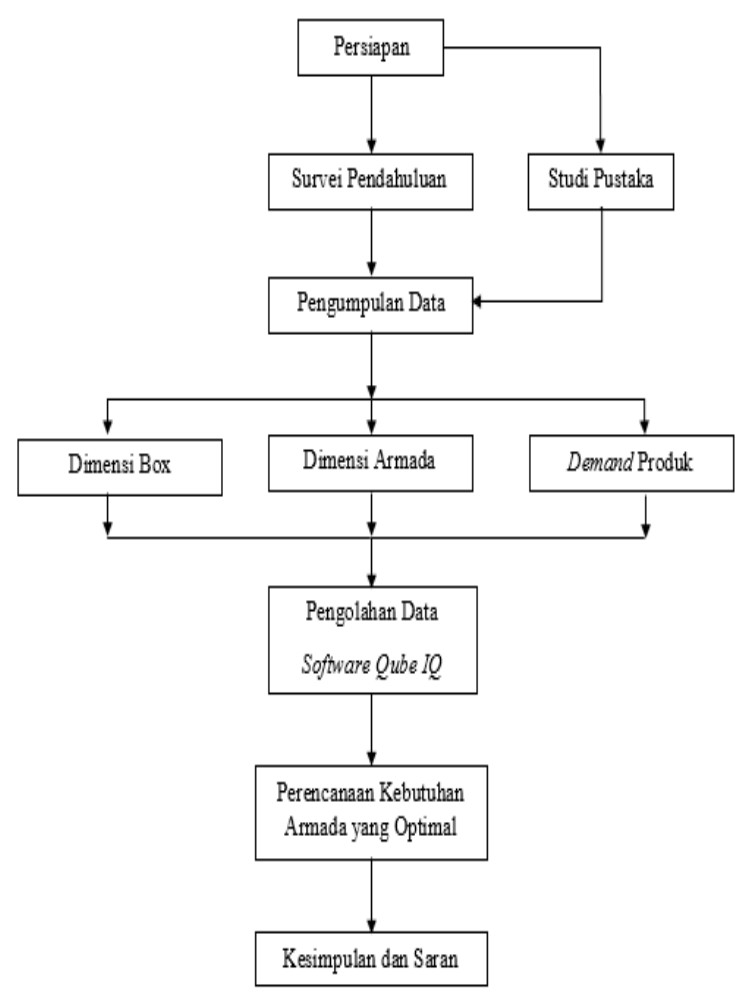

Gambar 1. Alur Penelitian

Proses pengumpulan data dilakukan dengan cara pengamatan dan pengukuran secara langsung pada aktivitas loading. Data yang diambil secara langsung yaitu ukuran kontainer data ini digunakan untuk mengatur sedemikian rupa barang di dalam kontainer dan memperkirakan barang tersebut dapat dirotasi maupun tidak. Gambar 2 visualisasikan kontainer secara 3D.

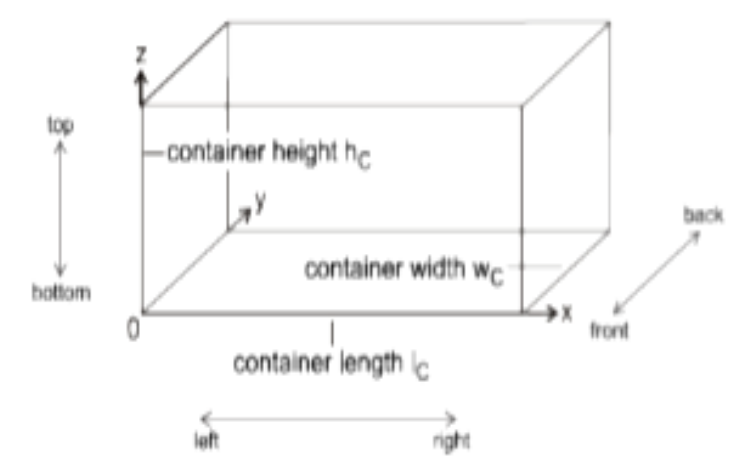

Gambar 2. Kontainer dalam visualisasi 3D

Penggambaran satu set kotak direpresentasikan dalam bentuk vector. Tinggi kontainer didefinisikan sebagai $h c$, lebar kontainer didefinisikan sebagai $w c$, dan panjang kontainer didefinisikan sebagai $/ c$.[9] 
Berbagai asumsi telah dibuat dalam rangka untuk menyederhanakan, memformulasikan dan menyelesaikan masalah penyusunan baranga pada kontainer ini. Beberapa asumsi yang dimaksud adalah sebagai berikut; Bidang yang digunakan berbentuk persegi panjang (kotak atau balok) dengan ukuran yang berbeda-beda. Rotasi barang yang akan dimuat didalam kontainer memungkinkan memiliki enam posisi. Posisi tersebut ditunjukkan pada Gambar 3 berikut:
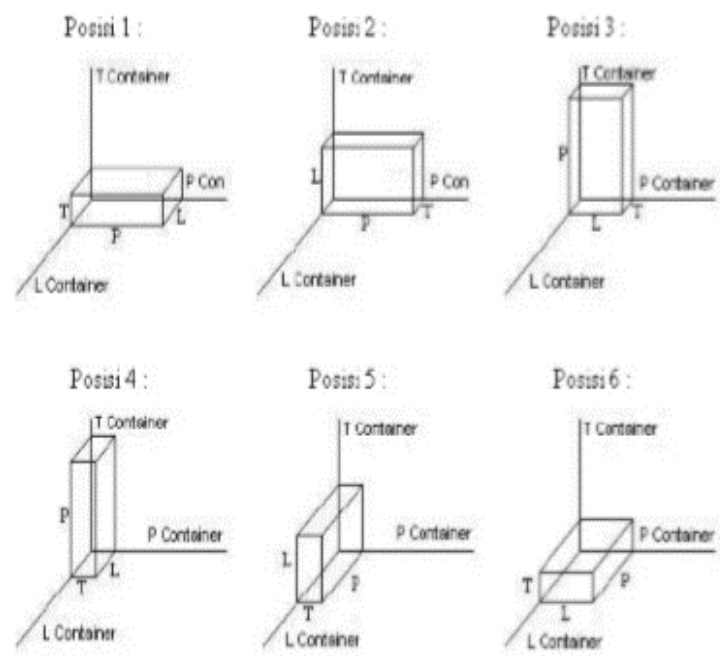

Gambar 3. Enam Kemungkinan Posisi Barang

Penyusunan barang didalam kontainer dimulai dari barang dengan ukuran paling besar yang diikuti dengan barang yang lebih kecil. Kotak yang berada paling atas didukung oleh kotak-kotak yang ada di bawahnya. Sisa ruang kosong diseimbangan dengan mengisi bagian celah antar kotak dengan menggunakan busa.

Pengolahan data dilakukan dengan menggunakan software Cube IQ. Penerapan perangkat lunak Cube $I Q$ dalam penelitian ini dilakukan untuk merencanakan penyusunan aktivitas loading sehingga memudahkan perusahaan tanpa mengeluarkan tenaga kerja, biaya, dan waktu yang lebih karena bentuk wadah apapun dapat didefinisikan dalam sistem untuk kesesuaian maksimum dengan kontainer fisik secara otomatis dengan menghasilkan peningkatan yang signifikan dibanding cara manual.[10] Terdapat berbagai kemungkinan bagi Cube IQ dalam aktivitas loading, yiatu:

a. Menciptakan 3D diagram beban rencana yang menggunakan aturan loading kompleks yang mencakup urutan loading, partial loads, dan pendistribusian beban.

b. Mengoptimalkan beban di bawah tumpukan secara menyeluruh, yang sesuai dengan aturan. c. Menyimpan kasus loading secara lengkap.

d. Mendistribusikan instruksi loading dalam diagram 3-D.

\section{HASIL DAN PEMBAHASAN}

Aktivitas loading di PT. ASR bermula ketika truk kontainer diparkirkan sejajar dengan staging area. Aktivitas loading yang dilakukan menggunakan metode manual loading dimana petugas loading yaitu untuk pengiriman ke kota Bekasi. Produk yang akan dikirimkan dan dimuat kedalam

Tabel 1. Produk yang akan dimuat

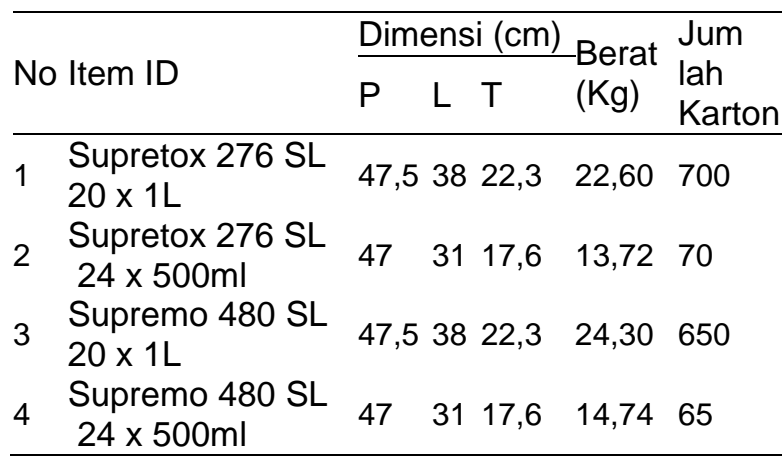

Armada yang digunakan oleh PT. ASR untuk melakukan proses pengiriman barang ke kota Bekasi yaitu kontainer dengan jenis Tronton Wingbox dengan dimensi kontainer seperti yang disampaikan pada Tabel 2 .

Tabel 2. Dimensi Kontainer

\begin{tabular}{lllll}
\hline Jenis Kontainer & \multicolumn{2}{l}{ Dimensi $(\mathrm{cm})$} & Kapasitas \\
\cline { 2 - 4 } & P & L & T & $\begin{array}{l}\text { Angkut } \\
(\mathrm{kg})\end{array}$ \\
\hline Tronton Wingbox & 940240290 & 35.000 \\
\hline
\end{tabular}

Setelah dilakukan pengolahan data selanjutnya melakan proses optimasi dengan menginput data kedalam software Cube IQ. Data yang diinput yaitu identitas produk, jumlah permintaan produk, berat dan dimensi master box pada setiap produk, dimana pada proses ini menghasilkan penyusunan barang yang optimal yang dapat dilihat hasilnya pada tampilan software. Proses ini ditunjukkan oleh Gambar 5. 


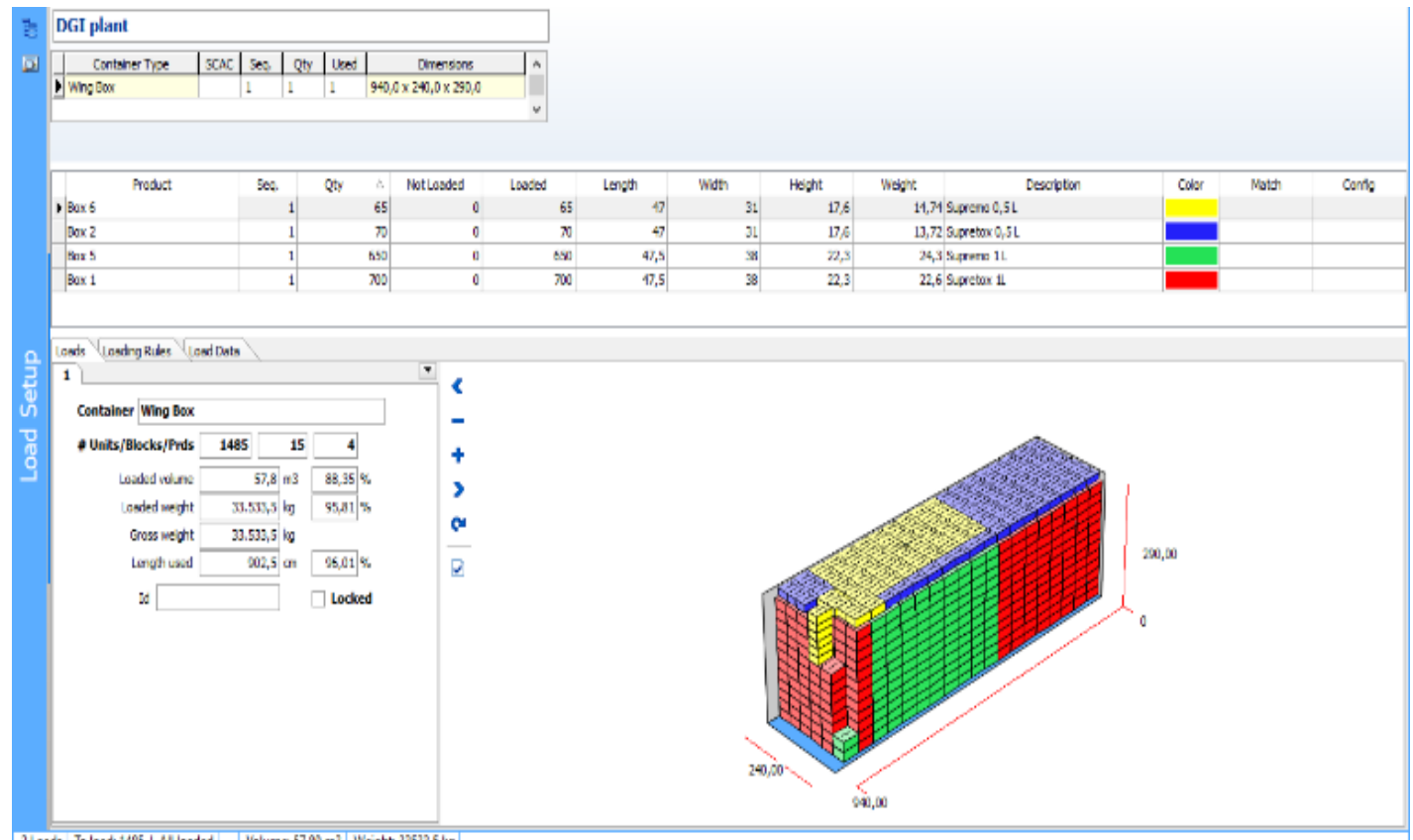

Gambar 4. Hasil Solusi Optimal

Utilitas dari kontainer setelah dilakukan optimasi menggunakan software Cube IQ ditampilkan oleh Gambar 5 .

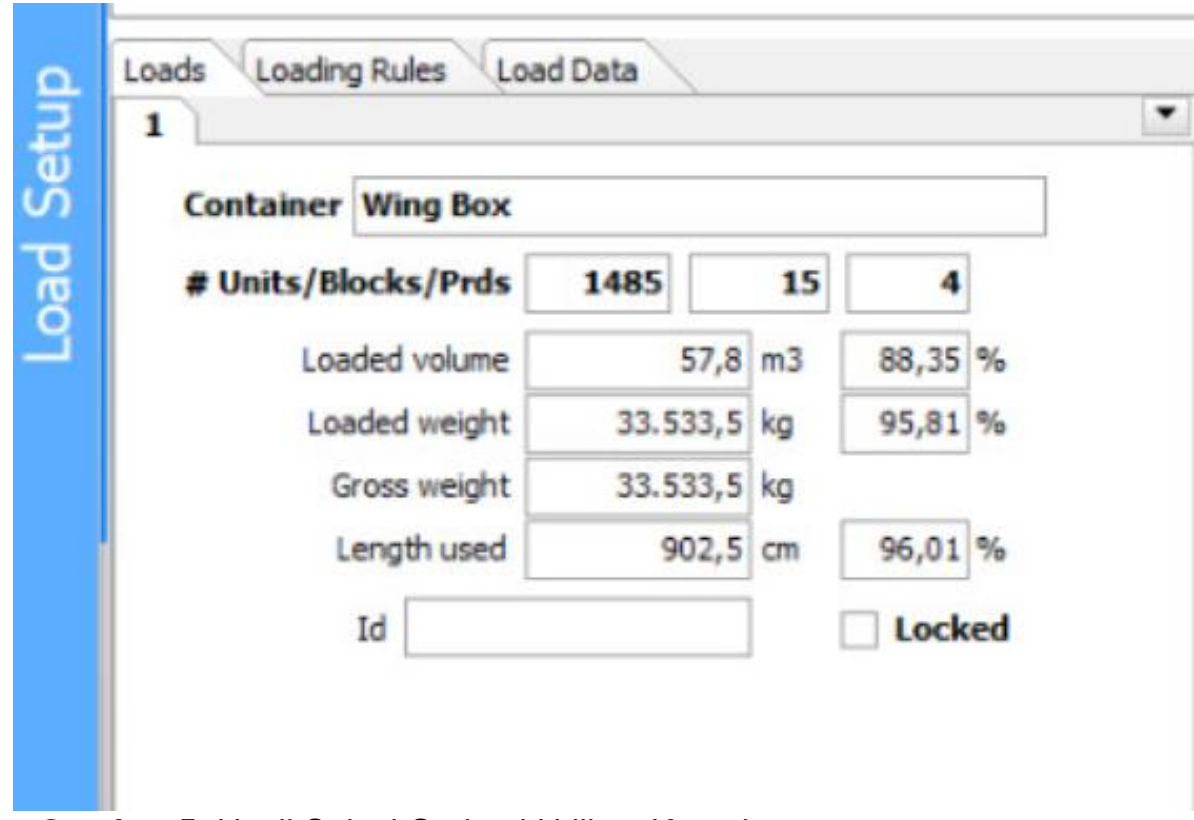

Gambar 5. Hasil Solusi Optimal Utilitas Kontainer

Hasil optimasi loading dapat dilihat secara visual yang ditampilkan dalam bentuk boxes, sehingga dapat dilihat seperti yang ditunjukan pada Gambar 6, 7, 8 dan 9 


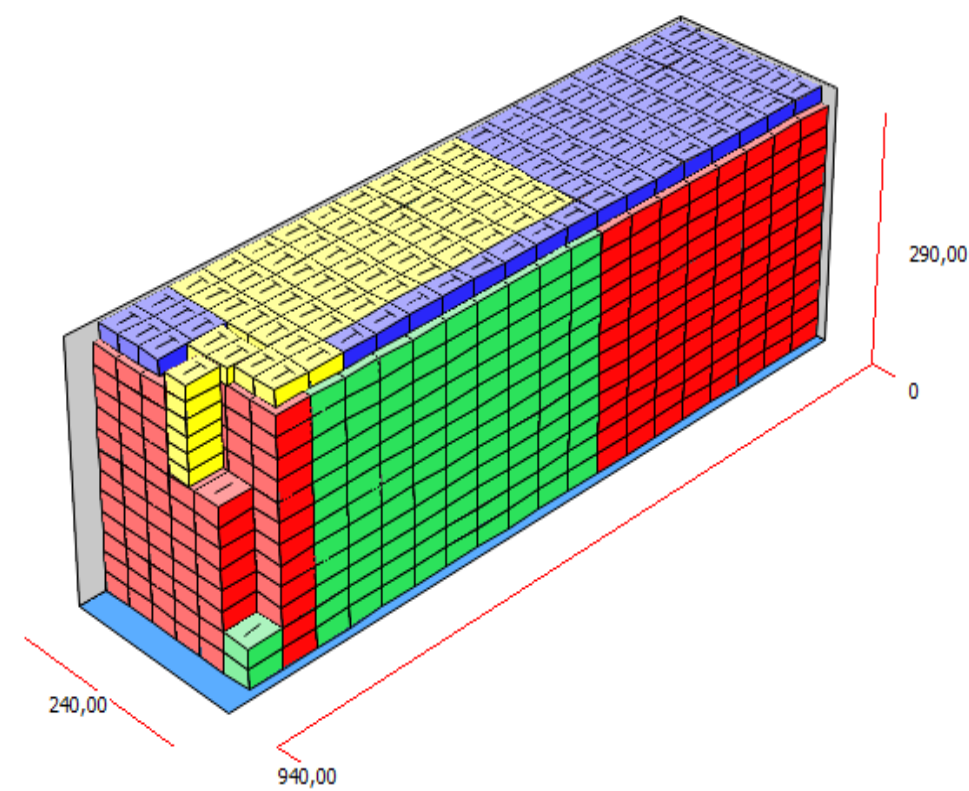

Gambar 6. Hasil Solusi Optimal (Boxes)
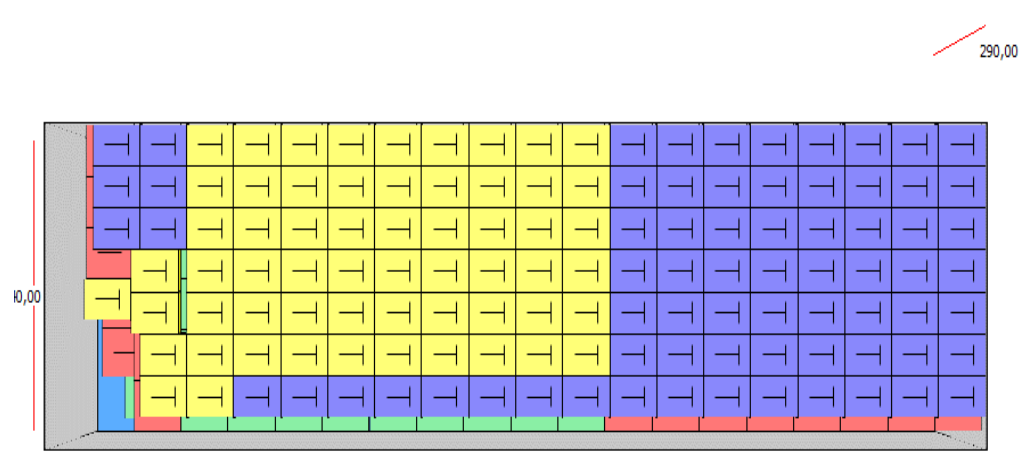

$\begin{array}{ll}\operatorname{Box} 1 & 700 \\ \operatorname{Box} 2 & 70 \\ \operatorname{Box} 5 & 650 \\ \operatorname{Box} 6 & 65\end{array}$

940,00

Gambar 7. Penyusunan Barang Tampak dari Atas

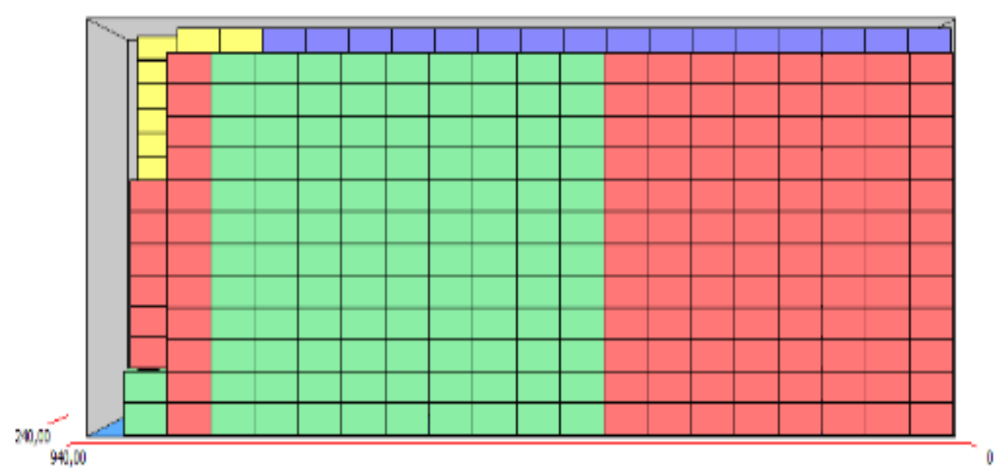

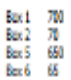

Gambar 8. Penyusunan Barang Tampak dari Kanan 

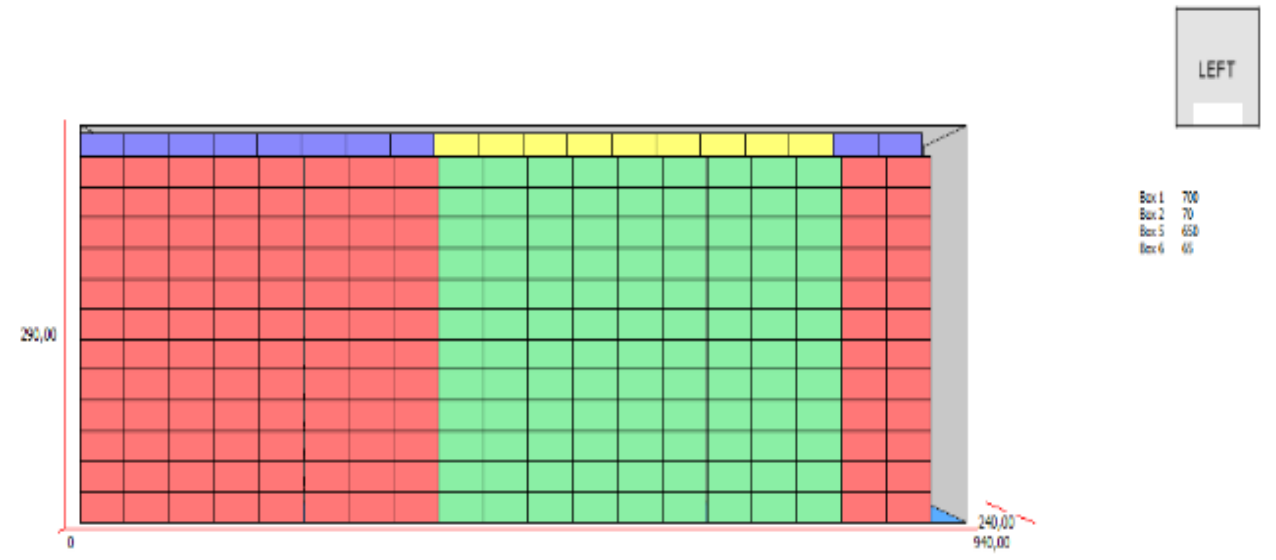

Gambar 9. Penyusunan Barang Tampak dari Kiri

Adapun Utilitas Kontainer Real Case dapat ditentukan dengan cara menghitungnya seperti berikut ini:

$$
\begin{gathered}
\text { Utilitas Kontainer }=\frac{A-(A-B)}{A} \times 100 \% \\
\text { Utilitas Kontainer }=\frac{65,42-(65,42-57,51)}{65,42} \times 100 \% \\
\text { Utilitas Kontainer }=\frac{65,42-7,91}{65,42} \times 100 \% \\
\text { Utilitas Kontainer }=87,91 \%
\end{gathered}
$$

Keterangan:

$A=$ Volume Total Kontainer $\left(\mathrm{m}^{3}\right)$

$\mathrm{B}=$ Volume Total Box $\left(\mathrm{m}^{3}\right)$

Hasil dari pengoptimalan muat barang menggunakan software Cube IQ sudah maksimal terlihat dari volume total box sudah termasuk celah antar box yang tidak dimungkinkan lagi untuk memuat barang sehingga perusahaan membutuhkan 1 unit armada untuk memenuhi demand dari pelanggan, tetapi untuk utilisasi kontainer terdapat perbedaan pada kedua kondisi seperti disampaikan pada Tabel 3.

Tabel 3. Perbedaan Utilisasi

\begin{tabular}{ll}
\hline Optimasi & $\begin{array}{l}\text { Utilisasi } \\
(\%)\end{array}$ \\
\hline Software Cube IQ & $88,35 \%$ \\
Real Case & $87,91 \%$ \\
\hline
\end{tabular}

Melihat hasil utilisasi kontainer pada penelitian yang dilakukan di PT. ASR bahwa penyusunan barang dalam aktivitas loading harus menjadi perhatian khusus sehingga akan menghasilkan beberapa keuntungan seperti:

a. Jumlah produk yang dapat dimuat bertambah

b. Tidak terjadi penambahan armada yang dapat memicu penambahan biaya. c. Efisiensi waktu muat barang, karena tidak terjadi penyusunan barang yang berulang.

Implikasi yang dirasakan setelah dilakukan optimasi yaitu pada biaya distribusi per unit, seperti yang disajikan pada Tabel 4 .

Tabel 4. Perbedaan Biaya

\begin{tabular}{llll}
\hline Optimasi & $\begin{array}{l}\text { Biaya } \\
\text { Distribusi }\end{array}$ & $\begin{array}{l}\text { Jumlah } \\
\text { Produk } \\
\text { (unit) }\end{array}$ & $\begin{array}{l}\text { Biaya } \\
\text { Per unit }\end{array}$ \\
\hline $\begin{array}{l}\text { Software } \\
\text { Cube IQ }\end{array}$ & Rp.1.800.000 & 1492 & Rp.1.206 \\
Real Case & Rp.1.800.000 & 1485 & Rp.1.212 \\
\hline
\end{tabular}

Melihat hasil perbedaan biaya ada penurunan sebesar $0,50 \%$.

\section{KESIMPULAN}

Dari hasil implementasi dan uji coba yang telah dilakukan terhadap penyusunan barang pada proses muat barang di PT.ASR menggunakan software Cube IQ, dapat ditarik kesimpulan bahwa ada peningkatkan utilitas kontainer sebesar $0,44 \%$ dengan utilisasi volume kontainer yang terpakai sebesar $57,8 \mathrm{~m}^{3}$ atau kurang lebih $88,35 \%$, utility panjang kontainer sebesar 902,5 $\mathrm{cm}$ atau kurang lebih $96,01 \%$ dan utility kapasitas berat kontainer sebesar $33.533,5 \mathrm{~kg}$ atau kurang lebih $95,81 \%$, serta ada penurunan pada biaya distribusi per unit sebesar $0,5 \%$ yang semula Rp.1.212 menjadi Rp.1.206.

Hasil optimasi saat ini masih belum menunjukan keadaan maksimum karena masih adanya space kosong dalam kontainer dikarenakan posisi box hanya bisa dimuat dalam satu posisi saja. Padahal jika dilihat space tersebut dapat dimanfaatkan apabila box dapat dimuat dengan posisi miring (vertical). 


\section{REFERENSI}

[1] M. A. Salam and S. A. Khan, "Simulation based decision support system for optimization: A case of Thai logistics service provider," Ind. Manag. Data Syst., vol. 116 , no. 2 , pp. $236-254$, 2016, doi: 10.1108/IMDS-05-2015-0192.

[2] R. Oktarina, "Aplikasi Software Cube lq Dalam Aktivitas Loading ( Studi Kasus : Pt X )," vol. 2010, no. Snati, pp. 63-67, 2010.

[3] F. Biaya, D. A. N. Fisik, and D. I. Pt, "Usulan Pemilihan Alternatif Tipe Crane Berdasarkan Faktor Biaya Dan Fisik Di Pt. Xyz," J. Tek. Ind. USU, vol. 4, no. 2, pp. 19-25, 2013.

[4] N. R. Andriyani, "Penentuan Rute Pendistribusian Produk Cat Menggunakan Capacitated Vehicle Routing Problem (CVRP) Dengan Mempertimbangkan Kapasitas Alat Angkut Berdasarkan Dimensi Kubikasi." Universitas Pasundan, Bandung, 2019.

[5] W. Kocjan and K. Holmström, "The Autopack project Algorithms for container loading Department of Mathematics and Physics Mälardalen University," vol. ISSN 1404-, 2010.

[6] J. F. Moura, A., \& Oliveira, "An integrated approach to the vehicle routing and container loading problems, Greece. In EURO XX-20th European conference on operational research.," pp. 1-21, 2014.

[7] N. Kunz, L. N. Van Wassenhove, R. McConnell, and K. Hov, "Centralized vehicle leasing in humanitarian fleet management: the UNHCR case," $J$. Humanit. Logist. Supply Chain Manag., vol. 5, no. 3, pp. 387-404, 2015, doi: 10.1108/JHLSCM-07-2015-0034.

[8] A. Tan, O. P. Hilmola, and D. H. Binh, "Matching volatile demand with transportation services in Vietnam: A case study with Gemadept," Asia Pacific J. Mark. Logist., vol. 28, no. 1, pp. 160-174, 2016, doi: 10.1108/APJML-05-2015-0079.

[9] W. Gazali and N. I. Manik, "Perancangan Program Simulasi Optimasi Penyusunan Barang dalam Kontainer menggunakan Algoritma Greedy," J. Mat Stat, vol. 10, no. 2, pp. 100-113, 2010.
[10] M. J. Suherlan, "Pengubahan Bentuk Kemasan Produk Untuk Meningkatkan Penggunaan Kapasitas Kontainer Dalam Pengiriman Produk Minuman Di PT XYZ," vol. 2, no. 2017. Universitas Widyatama, Bandung, pp. 227-249, 2018.

\section{Biografi Penulis}

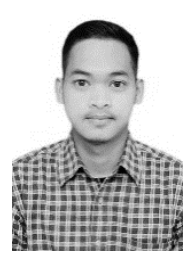

\section{Sri Wardani}

Sri Wardani lahir di Bandung 21 September 1996, merupakan seorang mahasiswa tingkat tiga. la sedang melakukan studi strata satu di Universitas Widytama Bandung.

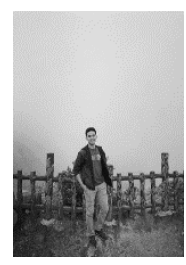

\section{Namun Mulyadi}

Namun Mulyadi Suprapto lahir di Batam, 5 Desember 1996. Saya lulusan dari Universitas Widyatama dengan jurusan Teknik Industri S1. Sekarang saya bekerja di PT.Sayap Mas Utama (Wings) bagian PPIC.

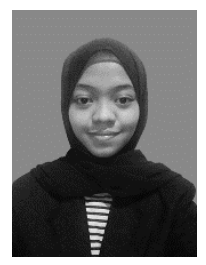

\section{Nitta Fitria Anggraeni}

Nitta Fitria Anggraeni, lahir di Bandung, 25 januari 1997. Aku berhasil menyelesaikan kuliahku tepat waktu pada tahun 2020 di Universitas Widyatama, Jurusan Teknik Industri S1. Prestasi yang pernah saya capai semasa kuliah yaitu mengikuti lomba design poster mengenai digitalisasi SCM pada produk kreatif yang diadakan oleh Institut Supply Chain dan Logistik Indonesia (ISLI) di Yogyakarta dan mendapatkan juara 2 tingkat Nasional. Aku juga berhasil mempublish 7 jurnal tingkat nasional bersama-sama temanku dan berhasil publish 1 paper bersakala internasional. 